the scalar-lead patterns are doubtful. In many cases of ostium-primum atrial septal defect the V.C.G. is radically different from that seen with an ostium-secundum defect. In theory, at least, it could distinguish between changes that are due to altered position of the heart from changes due to other causes. These are its chief clinical uses at the moment.

\section{Noise and Vision}

Q.- $A$ middle-aged man suffering from a stationary hypermetropia complains that his vision becomes blurred rhythmically in response to the ringing tone of a telephone; it also occurs as a temporary loss of accommodation with any loud, sudden noise. Is this a well-known condition?

A.-This is not a well-known condition. Any strong sensory stimulus tends to inhibit reception of other sensory stimuli. A strong auditory stimulus can be used to induce some degree of anaesthesia, for example, and is, I understand, being used for this purpose in the United States. This inhibition of pain presumably occurs in the higher centres and is probably not associated with accommodative changes.

\section{Hot Mud-packs}

Q. - What is the principle of hot mud-pack treatment for "rheumatism" as carried out at spas? Is it safe for a man aged 59 who has no signs of cardiovascular abnormality?

A.-A hot mud-pack is merely a form of applying moist heat, and is used in the treatment of painful joints at many spas. There is no evidence to support the contention that the various ingredients of the mud used have any therapeutic effect. Provided thermal sensation is normal and there is no abnormality of the skin, there are no contraindications to this form of treatment.

\section{Persisting Leucopenia in Pernicious Anaemia}

Q.-A patient with pernicious anaemia has a red blood count of about 5 million, but her white blood count is about 2,700, with normal proportions of white cells. She seems quite unable to resist any current infection that may be about. Is there any way of raising her white blood count?

A.-Adequate treatment of a patient with pernicious anaemia is usually followed by a return to normal values for the white blood cells as well as the red cells, haemoglobin, and platelets. Occasionally, however, the total white cell count does not go up to within the usually accepted normal range after cyanocobalamin therapy. When liver and stomach preparations were the usual forms of treatment for pernicious anaemia a good brisk response took place in all the cellular elements of the blood, and a persisting leucopenia was much more rarely observed.

The patient might be given a preparation of a relatively crude liver extract such as $\frac{1}{2} \mathrm{oz}$. (14.2 g.) of proteolysed liver orally daily. Most cases will respond to this form of treatment but not to the highly purified liver extracts for parenteral use. The response probably does not depend solely on cyanocobalamin or folic acid.

\section{Cortisone and Operations}

Q.-There appears to be some confusion about the effect of hydrocortisone and allied substances on minor operative procedures. I understand that patients undergoing a prolonged course of cortisone should have their dose increased considerably before general anaesthesia. Should similar precautions be taken before minor surgical procedures, such as tooth extractions, under local anaesthesia?

A.-There is indeed some confusion over this problem, largely owing to inability to predict the response of the individual patient. ${ }^{1}$ It is, however, well recognized that patients receiving corticosteroids may be incapable of responding adequately even to minor stress, and fatalities have been reported following operation. Moreover, such patients are sensitive to the effects of drugs, anaesthetics, and blood loss. Full recovery of adrenal function may not occur for up to two years after stopping corticosteroids. With these facts in mind, it is necessary to increase the dosage during the operative period, though this should be moderate rather than considerable, as stated in the question. because of the possibility-admittedly remote-of delayed healing and spread of infection. Suitable regimes were referred to in an annotation in the Journal. ${ }^{2}$ In the case of minor operations such as tooth extraction under local anaesthesia it is wise to double the dose for 48 hours and to warn the patient to report any untoward reaction at once.

\section{REFERENCES}

Salassa, R. M., Bennett, W. A., Keating, F. R.. jun., and Sprague. R. G J. Amer. med. Ass., 1953, 152, 1509.

Brit. med. J., 1959, 1, 1464

\section{NOTES AND COMMENTS}

Plantar Warts and Public Baths.-Dr. F. Groarke (Romford, Essex) writes: In the reply to a question relating to plantar warts ("Any Questions?" November 26, p. 1616) the following is stated: "Plantar warts and molluscum contagiosum are contagious ... and are spread through public baths." Could know what evidence exists in confirmation of the statement that they are spread through public baths?

OUR EXPERT replies: Dr. Groarke is correct in implying that there is no absolute proof, in the sense of the infective agent having been cultured from baths as in the case of ringworm infection of the feet. Unfortunately the infective agent of warts and mollusca remains very elusive. There is much circumstantial evidence, ${ }^{12}$ particularly in relation to epidemics in schools, supporting the hypothesis, but there can be no certainty until cultura proof is obtained.

$$
\begin{aligned}
& \text { REFERENCES } \\
& \begin{array}{l}
1 \text { Lyell, A., Lancet, 1955, 2, 349. } \\
2 \text { Low, R. C., Edinb. med. J., 1946, 53, } 657 .
\end{array}
\end{aligned}
$$

Napkin-rash.-Dr. Mary N. M. PAulin (Belfast) writes: Once again I am forced to write to you on the subject of napkin-rash to disagree with your expert ("Any Questions?" November 26, p 1616). I think napkin-rash is due to the interaction of nitrifying bacteria in the napkin and the urine resulting in the formation of ammonia which burns the skin. The mother of a baby with a sore bottom nearly always says, "The water smells very strong, doctor." The cure is not to boil the napkins-bacteria in napkins cannot be destroyed by ordinary domestic boiling, but they can be destroyed by ordinary domestic bleaching agents. I recommend that the napkins should be soaked overnight in bleach and then washed in the ordinary way with as many rinses as you like. The baby's bottom should be protected with a very liberal layer of zinc and castor oil cream. In the vast majority of cases this will cure the sore bottom which is in the raw and bleeding state.

Correction.-The figure given on p. 1817, Journal, December 17 , for additional registrations with the British United Provident Association should have read 38,423 and not 369,248 , which represents all registrations.

Collected Articles from the "British Medical Journal"

The following books are available through booksellers or from the Publishing Manager, B.M.A. House. Prices, which include postage, are now the same for both inland and overseas.

Refresher Course for General Practitioners, Volume 3 (26s. 9d.). Any Questions?, Volume 3 (8s. 3d.).

All communications with regard to editorial business should be addressed to THE EDITOR, BRITISH MEDICAL JOURNAL, B.M.A. HOUSE, TAVISTOCK SQUARE, LONDON, W.C.1. TELEPHONE: EUSTON 4499. TELEORAMS: Aitiology, Westcent, London. ORIGINAL ARTICLES AND LETTERS forwarded for publication are understood to be offered to the Brttish Medical Journal alone unless the contrary be stated.

Authors desiring REPRINTS should communicate with the Publishing Manager, B.M.A. House, Tavistock Square, W.C.1, on receipt of proofs. ADVERTISEMENTS should be addressed to the Advertisement Director. B A House Tavistock Square London W.C.1 (hours 9 i.m. B.M.A. House, Tavistock Square, London, W.C.1 (hours 9 a.m. to
5 p.m.). TELEPHONE: EUSTON 4499. Westcent, London.

MEMBERS' SUBSCRIPTIONS should be sent to the SECRETARY of the Association. TELEPHONE: BUSTON 4499. TELEGRAMS: Medtsecra,
Westcent, London.

B.M.A. SCOTtISH OFfice: 7, Drumsheugh Gardens, Edinburgh. 